ENTREPRENEURSHIP AND SUSTAINABILITY ISSUES

ISSN 2345-0282 (online) http://jssidoi.org/jesi/

2020 Volume 7 Number 3 (March)

http://doi.org/10.9770/jesi.2020.7.3(22)
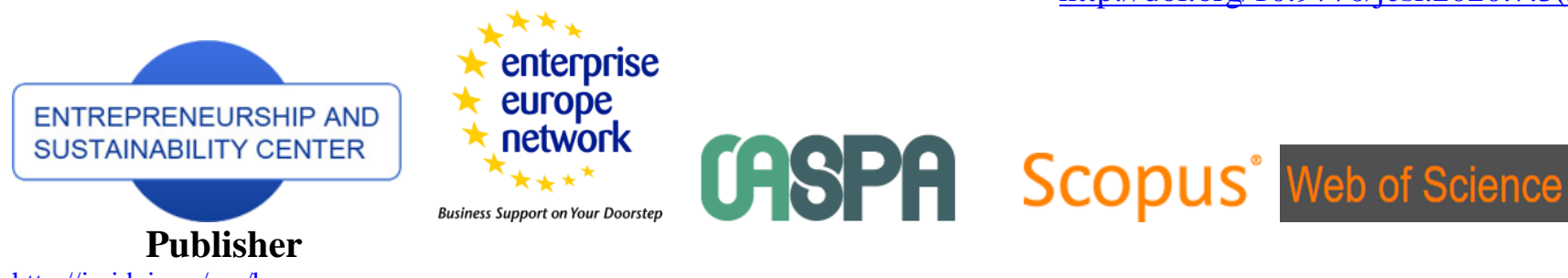

http://jssidoi.org/esc/home

Business Support on Your Doorste

\title{
I Clarivate Analytics \\ THE ANALYSIS OF THE COMPARATIVE EFFICIENCY OF STATE SUPPORT FOR NATURAL GAS PRODUCTION: THE CASE OF SOME OECD AND BRICS COUNTRIES
}

\author{
Alan Karaev ${ }^{1}$, Vadim Ponkratov ${ }^{2 *}$, Andrey Masterov ${ }^{3}$, Andrey Pozdnyaev ${ }^{4}$, Nikolay Kuznetsov ${ }^{5}$ \\ ${ }^{1,2,3}$ Financial University under the Government of the Russian Federation, Moscow, Russian Federation \\ ${ }^{4}$ Bauman Moscow State Technical University, Moscow, Russian Federation \\ ${ }^{5}$ State University of Management, Moscow, Russian Federation \\ E-mail: *ponkratovvadim@yandex.ru (Corresponding author)
}

Received 17 August 2019; accepted 15 December 2019; published 30 March 2020

\begin{abstract}
Energy subsidies stimulate excessive energy consumption, accelerate the depletion of natural resources, and reduce incentives for investment in green energy and renewable energy sources. In response to these factors, in 2009, the G-20 countries agreed to phase out fossil fuel subsidies. Subsidizing fossil fuels has significant economic consequences, such as creating artificial incentives for the development of traditional energy sectors, leading to unequal distribution of benefits from the development of natural resources among the population, as well as further burdening the state budget. In this research, the DEA method (Data Envelopment Analysis) is applied for a comparative cross-country analysis of the efficiency of government support for natural gas production in seven countries - the leading producers in the world - for the period 2013-2018; this comprised of four OECD countries with developed economies (USA, Canada, Norway, and Australia) and three BRICS countries with developing economies and emerging markets (China, Brazil, and Russia). An extended version of the DEA method allowed us to evaluate not only the technical efficiency but also the price efficiency of budget support for natural gas production in the considered countries. The data for the empirical model characterizing the extent of financial support extended to natural gas producers through budgetary transfers and tax expenditures were retrieved from the the OECD statistics database. The obtained results indicate the low efficiency of state support for natural gas production in Russia. The Russian government's policy is not directly aimed at an extensive development of the oil and gas sectors. Furthermore, urgent measures should be adopted to end inefficient energy subsidies that stimulate wasteful consumption of non-renewable raw materials and fossil fuels-an obligation for all G20 members. The economic and financial implications of ending fossil fuel subsidies should be comprehensively explored. In this regard, DEA models for evaluating the relative efficiency of state support for energy subsidies can be used as a powerful tool for solving a complex and crucial task of reforming the country's energy policy in line with global climate goals.
\end{abstract}

Keywords: subsidies; government support; fiscal measures; energy subsidies; natural gas production; operational environment; operational efficiency; DEA method

Reference to this paper should be made as follows: Karaev, A. K., Ponkratov, V. V., Masterov, A. I., Pozdnyaev, A. S., Kuznetsov, N. V. 2020. The analysis of the comparative efficiency of state support for natural gas production: the case of some OECD and BRICS countries. Entrepreneurship and Sustainability Issues, 7(3), 1778-1789. https://doi.org/10.9770/jesi.2020.7.3(22)

JEL Classifications: H39, H54, C60

Additional disciplines: ecology and environment; electricity electronic engineering; environmental engineering 


\section{ENTREPRENEURSHIP AND SUSTAINABILITY ISSUES}

ISSN 2345-0282 (online) http://jssidoi.org/jesi/

2020 Volume 7 Number 3 (March)

http://doi.org/10.9770/jesi.2020.7.3(22)

\section{Introduction}

The most common argument in favor of energy subsidies revolves around the possibility of developing the industry and agriculture, creating jobs, providing access to energy services, and reducing poverty (IEA, 2015).

However, expected preferences carry significant state expenditures. At the same time, energy subsidies reduce the potential of national economies to grow, and contribute to the inefficient use of raw materials and energy resources. Subsidizing fossil fuels triggers the excessive consumption of these materials and resources and hinders the development of renewable energy sources (Stiglitz et al., 2017), which often leads to increased emissions of carbon dioxide and other greenhouse gases; that is, it is harmful to the environment (Grigoriev and Kurdin, 2014).

An IMF report (2019) presented data on energy subsidies in 191 countries. According to this report, government subsidies for fossil fuels are still significant; for instance, in 2015 their total amount was USD 4.7 trillion, or $6.3 \%$ of the world GDP. China spent the most (USD 1.4 trillion), followed by the United States (USD 649 billion), Russia (USD 551 billion), the European Union (USD 289 billion), and India (USD 209 billion). According to IMF forecasts, energy subsidies will remain high in 2020, and this figure will increase globally up to USD 5.8 trillion, or $6.7 \%$ of the GDP.

Various international environmental funds, led by the IMF, support the reduction of energy subsidies and believe that their funding is expensive for the country and may impede government efforts to reduce budget deficits. Subsidies also contribute to excessive energy consumption, accelerating the depletion of natural resources and reducing incentives for investments in other nonpolluting energy sectors.

As early as 2009, the G20 had called for the phasing out of fossil fuel subsidies worldwide and had reiterated this call in 2012. In line with the recent activities of the G20, the following criteria for classifying energy subsidies seem particularly relevant: the type of subsidized energy source (fossil fuel or other types of energy carriers) and the efficiency of subsidies.

In this research, we performed a cross-country analysis of the comparative efficiency of energy subsidies, in particular, government support for natural gas production in the OECD countries with developed economies (the USA, Canada, Norway, and Australia) and some developing BRICS countries (China, Brazil, and Russia) for the period from 2013 to 2018.

Actually, the OECD has developed a number of methods to evaluate the scale of financial support for a producer and a consumer through energy subsidies, even with limited data.

The OECD documents often use the term "government support measures" for the broadest interpretation of subsidies in the fuel and energy complex.

In this research, the comparative efficiency of state support for natural gas production was analyzed using the OECD methodology for subsidies evaluation - the OECD Inventory of Support Measures for Fossil Fuels (hereinafter referred to as the Inventory) that provide preferences to both consumers and producers of fossil fuels. In total, the Inventory includes 44 countries: 36 OECD countries and 8 partner countries (Argentina, Brazil, China, Colombia, India, Indonesia, Russia, and South Africa), and it reports about nearly 1,200 individual fossil fuel support measures in these states (OECD, 2019).

According to the Inventory, in 2017 the OECD member and partner countries provided about USD 140 billion for support of fossil fuels, which is $40 \%$ below the highest level of 2013. The total government support in OECD 


\section{ENTREPRENEURSHIP AND SUSTAINABILITY ISSUES}

ISSN 2345-0282 (online) http://jssidoi.org/jesi/

2020 Volume 7 Number 3 (March)

http://doi.org/10.9770/jesi.2020.7.3(22)

countries and individual partner countries decreased by $9 \%$ between 2016 and 2017, which is smaller than a decrease of 12\% that took place between 2015 and 2016, and a 19\% decrease between 2014 and 2015.

\section{Methodology}

The efficiency of state power and its governing bodies can be increased by developing formalized methods and criteria for quantifying the efficiency of the entire public sector (Onrubia-Fernández and Jesús Sánchez Fuentes, 2017). Currently, the most common tool for evaluating the efficiency of the state activities is non-parametric methods for analyzing the operational environment (Data Envelopment Analysis, DEA (Emrouznejad et al., 2008)), in which the state consumes the resources of society and produces public goods (safety, health, infrastructure, etc.) (Akhremenko, 2013a).

However, the process of converting resources into results is not considered within the DEA method, i.e. the system is represented as a "black box", efficiency is determined as a ratio of costs and results, but is not based on the internal characteristics of Decision-Making Units (DMUs). Therefore, this approach does not focus on the structure of the analyzed systems, and one can comprehensively explore their characteristics.

In the quantitative evaluation of the efficiency of the public sector, as a rule, one takes budget expenditures for providing various public goods as input variables, whereas the achieved level of public welfare in a particular area is considered as an output parameter of the model.

The method of Data Envelopment Analysis. A nonparametric method for evaluating the technical efficiency of a set of similar companies was first developed by Farrell (1957). Later, this method was substantially developed in the works of Debreu (1951), Koopmans (1951), Forsund and Hjalmarsson (1974), Charnes et al. (1985), and Tone (2001).

Nevertheless, all traditional DEA models can be used to measure the technical efficiency of DMUs, but they cannot be applied for benchmarking and ranking DMUs, since for this one needs to know price efficiency of the compared DMUs.

To overcome the above disadvantages of traditional DEA methods, Khezrimotlagh et al. (2013) developed an approach that evaluates the efficiency of companies according to the $\varepsilon-\mathrm{KAM}$ method (Kourosh and Arash Method). It uniformly connects two concepts and provides estimates for calculating both technical and price efficiency.

In this research, we performed a cross-country analysis of the comparative efficiency of energy subsidies - in particular, government support for natural production in seven countries, the leading producers of natural gas: four OECD countries with developed economies (the USA, Canada, Norway, and Australia) and three developing BRICS countries (China, Brazil, and Russia) for the period from 2013 to 2018 with the $\varepsilon$-KAM method.

The DEA method uses simultaneous input and output indicators, which sometimes leads to incorrect results because budget investment flows precede the results, but do not occur at the same time. Therefore, in this study we replaced budget investment flow with accumulated budget investments (Akhremenko, 2013). For example, considering the data for 2010-2013, the input indicator of the model will be the sum of $X(2010)+X(2011)+$ $\mathrm{X}(2012)$, and the output indicator will be $\mathrm{Y}(2013)$. 


\section{Initial data for the analysis of state support efficiency}

In the empirical model, the cross-country analysis of the comparative efficiency of state support for natural gas production was performed for a sample of seven countries: four OECD countries (the USA, Canada, Norway, and Australia) and three BRICS countries (China, Brazil, and Russia). The initial data covered the period from 2013 to 2018 and were taken from the statistical databases of the Organization for Economic Co-operation and Development (OECD).

We selected the following annual indicators for each country in the sample:

$\mathrm{X} 1$ - annual budgetary transfers to natural gas producers, million units in national currency;

$\mathrm{X} 2$ - annual tax expenditures for natural gas producers, million units in national currency;

Y1 - annual production of natural gas, million tons.

To recalculate government support indicators X1 and X2 that were expressed in the national currency of each country as a share of the country's GDP, we used annual data on the countries' GDP from the statistical database of the international organization-OECD Data, Gross Domestic Product (GDP).

Table 1 presents data on the world's annual production of natural gas (billion cubic meters), including country unions - OECD, BRICS, G7, Europe, and the European Union; some OECD countries - the USA, Canada, Norway, and Australia; and some BRICS countries - China, Brazil, and Russia for the period from 2010 to 2018.

As can be seen from Table 1, over the period from 2010 to 2017 the production of natural was steadily increasing worldwide, for instance, in the OECD, BRICS, G7, except for Europe and the European Union.

The most significant growth in natural gas production between 2000 and 2018 occurred in the USA (average annual growth of $2.6 \%$ ), Norway (4.8\% per year), Brazil (6.8\% per year), Australia (7.7\% per year), and China (10.4\% in year). 
Table 1. Natural gas production in some OECD countries (USA, Canada, Norway, and Australia) and the BRICS (Russia, Brazil, and China), billion cubic meters, 2010-2018.

\begin{tabular}{|c|c|c|c|c|c|c|c|c|c|c|}
\hline & 2010 & 2011 & 2012 & 2013 & 2014 & 2015 & 2016 & 2017 & 2018 & $\begin{array}{c}2000- \\
2018 \\
(\% / y e a r)\end{array}$ \\
\hline World & 3280 & 3369 & 3423 & 3492 & 3541 & 3590 & 3628 & 3781 & 3975 & 2,6 \\
OECD & 1185 & 1206 & 1230 & 1238 & 1277 & 1305 & 1319 & 1363 & 1454 & 1,5 \\
G7 & 850 & 882 & 902 & 902 & 956 & 991 & 989 & 1014 & 1108 & 1,3 \\
BRICS & 821 & 843 & 829 & 852 & 833 & 829 & 837 & 901 & 957 & 2,3 \\
Europe & 317 & 292 & 294 & 287 & 269 & 261 & 259 & 260 & 240 & $-1,6$ \\
European Union & 206 & 185 & 174 & 173 & 155 & 139 & 138 & 131 & 112 & $-4,7$ \\
Norway & 110 & 106 & 119 & 113 & 113 & 121 & 121 & 128 & 127 & 4,9 \\
Russia & 657 & 673 & 658 & 675 & 647 & 638 & 644 & 694 & 741 & 1,4 \\
Canada & 160 & 160 & 156 & 156 & 164 & 165 & 174 & 181 & 188 & 0,2 \\
United States & 604 & 649 & 681 & 686 & 733 & 767 & 755 & 775 & 864 & 2,6 \\
Brazil & 15 & 17 & 19 & 21 & 23 & 23 & 24 & 26 & 23 & 6,8 \\
China & 96 & 105 & 111 & 121 & 130 & 135 & 137 & 148 & 160 & 10,4 \\
Australia & 53 & 56 & 54 & 62 & 63 & 67 & 87 & 109 & 125 & 7,7 \\
\hline
\end{tabular}

Source: Global Energy Statistical Yearbook 2019 (GESY, 2019)

Table 2 shows numerical values of state (fiscal) support for natural gas production in some OECD countries with developed economies (the USA, Canada, Norway, and Australia) and the BRICS countries (China, Brazil, and Russia) for 2010-2018. The amount of subsidies is given in the national currency of the country (million units). The last column of Table 2 presents the data on the GDP of the considered countries (million units of the national currency).

Table 2. State support for natural gas production in some OECD countries (the USA, Canada, Norway, and Australia) and the BRICS (China, Brazil, and Russia), 2010-2018

\begin{tabular}{|c|c|c|c|c|}
\hline Indicators & $\begin{array}{c}\text { X1-Fossil fuel } \\
\text { subsides, Budgetary } \\
\text { Transfers, mln units }\end{array}$ & $\begin{array}{l}\text { X2-Fossil fuel subsides, Tax } \\
\text { Expenditure, mln units }\end{array}$ & $\begin{array}{c}\text { Y1- Production (annual) } \\
\text { of } \\
\text { Natural Gas, Bln cubic }\end{array}$ & $\begin{array}{c}\text { GDP, } \\
\text { in National } \\
\text { Currency, mln units }\end{array}$ \\
\hline 2010,USA & 49.1582 & 1126.4 & 604. & $1.49921 * 10^{\wedge} 7$ \\
\hline 2011,USA & 134.818 & 1090.9 & 649. & $1.55426^{*} 10^{\wedge} 7$ \\
\hline 2012,USA & 76.283 & 1087.46 & 681. & $1.6197 * 10^{\wedge} 7$ \\
\hline 2013,USA & 20.8615 & 1022.13 & 686. & $1.67849 * 10^{\wedge} 7$ \\
\hline 2014,USA & 19.3448 & 847.925 & 733. & $1.75217 * 10^{\wedge} 7$ \\
\hline 2015,USA & 0.0 & 1163.29 & 767. & $1.82193 * 10^{\wedge} 7$ \\
\hline 2016,USA & 0.0 & 903.86 & 755. & $1.87072 * 10^{\wedge} 7$ \\
\hline 2017, USA & 0.0 & 441.418 & 775. & $1.94854 * 10^{\wedge} 7$ \\
\hline 2010,CAN & 0.0 & 1398.49 & 160. & $1.66213 * 10^{\wedge} 6$ \\
\hline 2011,CAN & 0.0 & 557.55 & 160. & $1.76992 * 10^{\wedge} 6$ \\
\hline 2012,CAN & 0.0 & 696.262 & 156. & $1.82281 * 10^{\wedge} 6$ \\
\hline 2013,CAN & 0.0 & 937.587 & 156. & $1.89753 * 10^{\wedge} 6$ \\
\hline 2014,CAN & 0.0 & 1166.08 & 164. & $1.99018 * 10^{\wedge} 6$ \\
\hline 2015,CAN & 0.0 & 672.162 & 165. & $1.98583^{*} 10^{\wedge} 6$ \\
\hline 2016,CAN & 0.0 & 752.544 & 174. & $2.02382 * 10^{\wedge} 6$ \\
\hline
\end{tabular}




\section{ENTREPRENEURSHIP AND SUSTAINABILITY ISSUES}

ISSN 2345-0282 (online) http://jssidoi.org/jesi/

2020 Volume 7 Number 3 (March)

http://doi.org/10.9770/jesi.2020.7.3(22)

\begin{tabular}{|c|c|c|c|c|}
\hline 2017,CAN & 0.0 & 864.808 & 181. & $2.13753 * 10^{\wedge} 6$ \\
\hline 2010,NOR & 0 & 34.9049 & 110. & $2.59374 * 10^{\wedge} 6$ \\
\hline 2011, NOR & 0. & 29.8241 & 106. & $2.79576^{*} 10^{\wedge} 6$ \\
\hline 2012, NOR & 0. & 21.8834 & 119. & $2.96826^{*} 10^{\wedge} 6$ \\
\hline 2013,NOR & 0. & 40.7446 & 113. & $3.07558 * 10^{\wedge} 6$ \\
\hline 2014, NOR & 0. & 45.1141 & 113. & $3.14667 * 10^{\wedge} 6$ \\
\hline 2015, NOR & 0. & 43.4124 & 121. & $3.11812 * 10^{\wedge} 6$ \\
\hline 2016,NOR & 0. & 54.4323 & 121. & $3.1193 * 10^{\wedge} 6$ \\
\hline 2017, NOR & 0. & 65.3188 & 128. & $3.30444 * 10^{\wedge} 6$ \\
\hline 2010,AUS & 0.0 & 0.853524 & 53. & $1.36316^{*} 10^{\wedge} 6$ \\
\hline 2011,AUS & 0.0 & 0.201326 & 56. & $1.46749 * 10^{\wedge} 6$ \\
\hline 2012,AUS & 0.0 & 0.202808 & 54. & $1.51529 * 10^{\wedge} 6$ \\
\hline 2013,AUS & 0.0 & 0.220175 & 62. & $1.56812 * 10^{\wedge} 6$ \\
\hline 2014,AUS & 0.0 & 0.223768 & 63. & $1.614^{*} 10^{\wedge} 6$ \\
\hline 2015,AUS & 0.0 & 0.229257 & 67. & $1.6408 * 10^{\wedge} 6$ \\
\hline 2016,AUS & 0.0 & 0.229257 & 87. & $1.70525^{*} 10^{\wedge} 6$ \\
\hline 2017,AUS & 0.0 & 0.22 & 109. & $1.80793 * 10^{\wedge} 6$ \\
\hline $2010, \mathrm{CHN}$ & 924.201 & 3855.47 & 96. & $4.12119 * 10^{\wedge} 7$ \\
\hline $2011, \mathrm{CHN}$ & 1297.47 & 6802.6 & 105. & $4.8794 * 10^{\wedge} 7$ \\
\hline $2012, \mathrm{CHN}$ & 1389.89 & 9759.08 & 111. & $5.3858 * 10^{\wedge} 7$ \\
\hline $2013, \mathrm{CHN}$ & 1621.35 & 11138.5 & 121. & $5.92963 * 10^{\wedge} 7$ \\
\hline 2014,CHN & 2243.33 & 9750.75 & 130. & $6.41281 * 10^{\wedge} 7$ \\
\hline $2015, \mathrm{CHN}$ & 3703.46 & 7811.84 & 135. & $6.85993 * 10^{\wedge} 7$ \\
\hline 2016,CHN & 5158.18 & 5829.08 & 137. & $7.40061 * 10^{\wedge} 7$ \\
\hline $2017, \mathrm{CHN}$ & 6248.17 & 9973.88 & 148. & $8.20754 * 10^{\wedge} 7$ \\
\hline 2010,BRA & 3.74378 & 120. & 15. & $3.88585 * 10^{\wedge} 6$ \\
\hline 2011,BRA & 5.11545 & 185.842 & 17. & $4.37638^{*} 10^{\wedge} 6$ \\
\hline 2012,BRA & 2.86141 & 405.168 & 19. & $4.81476^{*} 10^{\wedge} 6$ \\
\hline 2013,BRA & 4.21879 & 164.192 & 21. & $5.33162 * 10^{\wedge} 6$ \\
\hline 2014,BRA & 3.2925 & 28.5536 & 23. & $5.77895 * 10^{\wedge} 6$ \\
\hline 2015,BRA & 1.44321 & 57.1927 & 23. & $5.99579 * 10^{\wedge} 6$ \\
\hline 2016,BRA & 0.300079 & 42.7873 & 24. & $6.26721 * 10^{\wedge} 6$ \\
\hline 2017,BRA & 0.254052 & 24.456 & 26. & $6.55384 * 10^{\wedge} 6$ \\
\hline 2010,RUS & 4560.41 & 6485.88 & 657. & $4.98791 * 10^{\wedge} 7$ \\
\hline 2011,RUS & 4492.47 & 8326.94 & 673. & $6.02825^{*} 10^{\wedge} 7$ \\
\hline 2012,RUS & 6528.45 & 8966.89 & 658. & $6.81639 * 10^{\wedge} 7$ \\
\hline 2013,RUS & 7981.78 & 8892.75 & 675. & $7.31339 * 10^{\wedge} 7$ \\
\hline 2014,RUS & 3753.86 & 8017.3 & 647. & $7.91997 * 10^{\wedge} 7$ \\
\hline 2015,RUS & 3595.76 & 4458.49 & 638. & $8.32326^{*} 10^{\wedge} 7$ \\
\hline 2016,RUS & 4049.49 & 3504.41 & 644. & $8.60436^{*} 10^{\wedge} 7$ \\
\hline 2017,RUS & 5403.26 & 5037.07 & 694. & $9.21013 * 10^{\wedge} 7$ \\
\hline
\end{tabular}

Source: the authors' calculations with the data from Global Energy Statistical Yearbook 2019 (GESY, 2019) and OECD Inventory of Support Measures for Fossil Fuels database (OECD, 2019)

As can be seen from Table 2, most OECD countries producing natural gas (Canada, Norway, Australia, and partially the USA (since 2015) do not support the production of natural gas in the form of direct budgetary transfers: these subsidies are granted in the form of tax preferences.

\section{The results of the analysis of state support efficiency}

Table 3 presents the results of the model experiments with the $\varepsilon$-KAM method within the cross-country analysis of the comparative efficiency of government support for natural gas production or energy subsidies efficiency in some OECD countries (the USA, Canada, Norway, and Australia), and in the BRICS (China, Brazil, and Russia) for the period from 2013 to 2018. 
As follows from Table 3, the OECD countries - natural gas producers with developed economies (the USA, Australia, and Canada) have the highest technical and price efficiency of state support (numerically expressed in units of the country's GDP) for natural gas production in the analyzed sample: in 2018 state support for natural gas production in these countries was on the borderline of technical and price efficiency (KAM-score=1.0). This, according to the $\varepsilon$-KAM method, means that there is no need to change the combination of input and output indicators of the model.

For the period from 2013 to 2018, in the analyzed countries the average values of the technical and price efficiency of state support (numerically expressed in units of the country's GDP) of natural gas production were highest in the OECD countries (the USA, Canada, and Australia). The USA had the highest price efficiency of state support for natural gas production averaged for the period from 2013 to 2018, while Australia had the highest technical efficiency averaged over the same period.

The developing BRICS countries, China and Brazil had the lowest indicators of both technical and price efficiency of state support for natural gas production (numerically expressed in units of the country's GDP) among the analyzed seven countries.

According to Table 3, in 2018 Russia had rather low values of both technical and price efficiency of state support for natural gas production (numerically expressed in units of the country's GDP) among the analyzed seven countries (KAM-score $=0.389, \varepsilon=10-7$ and KAM-score $=0.410, \varepsilon=1.0$ ), which are very far from the borderline and the technical and price efficiency of state support for natural gas producers in the analyzed countries.

In terms of both technical and price efficiency of state support for natural gas production (numerically expressed in units of the country's GDP) for the period from 2013 to 2018, Russia's indicators were comparable to those of Norway, although Russia had slightly higher values than this country.

Table 3. Indicators of the efficiency of state support for natural gas production in the USA, Canada, Norway, Australia, and the BRICS (China, Brazil, and Russia), 2010-2018

\begin{tabular}{|c|c|c|c|}
\hline Efficiency Indicators & $\begin{array}{c}\text { KAM-score } \\
\end{array}$ & $\begin{array}{c}\text { KAM- } \\
\text { score, } \\
\varepsilon=10-1\end{array}$ & $\begin{array}{c}\text { KAM-score } \\
\varepsilon=1.0 . \text { Price efficiency }\end{array}$ \\
\hline 2013, USA & 0.252 & 0.401 & 0.53 \\
\hline 2014, USA & 0.289 & 0.38 & 0.59 \\
\hline 2015, USA & 0.34 & 0.44 & 0.68 \\
\hline 2016, USA & 0.42 & 0.721 & 0.804 \\
\hline 2017, USA & 0.58 & 1. & 0.863 \\
\hline 2018, USA & 1. & 0.597 & 1. \\
\hline Mean(2013-2018),USA & 0.480 & 0.258 & 0.745 \\
\hline 2013, CAN & 0.250 & 0.28 & 0.262 \\
\hline 2015, CAN & 0.279 & 0.304 & 0.290 \\
\hline 2016, CAN & 0.304 & 0.4 & 0.308 \\
\hline 2017, CAN & 0.382 & 0.521 & 0.404 \\
\hline 2018, CAN & 0.48 & 0.898 & 0.563 \\
\hline Mean(2013-2018),CAN & 1. & 0.460 & 0886. \\
\hline 2013, NOR & 0.449 & 0.204 & 0.471 \\
\hline 2015, NOR & 0.2016 & 0.2058 & 0.2048 \\
\hline 2016, NOR & 0.2023 & 0.2062 & 0.2060 \\
\hline
\end{tabular}


ENTREPRENEURSHIP AND SUSTAINABILITY ISSUES

ISSN 2345-0282 (online) http://jssidoi.org/jesi/

2020 Volume 7 Number 3 (March)

http://doi.org/10.9770/jesi.2020.7.3(22)

\begin{tabular}{|c|c|c|c|}
\hline 2017, NOR & 0.205 & 0.2082 & 0.2094 \\
\hline 2018, NOR & 0.2055 & 0.2096 & 0.2098 \\
\hline Mean(2013-2018),NOR & 0.204 & 0.207 & 0.208 \\
\hline 2013, AUS & 0.318 & 0.38 & 0.43 \\
\hline 2014, AUS & 0.465 & 0.465 & 0.465 \\
\hline 2015, AUS & 0.501 & 0.5 & 0.5 \\
\hline 2016, AUS & 0.655 & 0.687 & 0.788 \\
\hline 2017, AUS & 0.738 & 0.783 & 0832. \\
\hline 2018, AUS & 1. & 0.843 & 0.645 \\
\hline Mean(2013-2018),AUS & 0.612 & 0.635 & 0.1022 \\
\hline 2013, CHN & 0.1022 & 0.1022 & 0.102 \\
\hline 2014, CHN & 0.102 & 0.102 & 0.1019 \\
\hline 2015, CHN & 0.102 & 0.1019 & 0.1024 \\
\hline 2016, CHN & 0.1023 & 0.1024 & 0.1035 \\
\hline 2017, CHN & 0.1033 & 0.1035 & 0.1041 \\
\hline 2018, CHN & 0.104 & 0.1041 & 0.103 \\
\hline Mean(2013-2018),CHN & 0.103 & 0.103 & 0.112 \\
\hline 2013, BRA & 0.11 & 0.112 & 0.113 \\
\hline 2014, BRA & 0.111 & 0.112 & 0.116 \\
\hline 2015, BRA & 0.115 & 0.116 & 0.134 \\
\hline 2016, BRA & 0.133 & 0.134 & 0.156 \\
\hline 2017, BRA & 0.155 & 0.156 & 0.154 \\
\hline 2018, BRA & 0.152 & 0.153 & 0.130 \\
\hline Mean(2013-2018),BRA & 0.129 & 0.130 & 0.255 \\
\hline 2013, RUS & 0.232 & 0.267 & 0.245 \\
\hline 2014, RUS & 0.229 & 0.232 & 0.258 \\
\hline 2015, RUS & 0.24 & 0.244 & 0.296 \\
\hline 2016, RUS & 0.2681 & 0.283 & 0.328 \\
\hline 2017, RUS & 0.277 & 0.287 & 0.41 \\
\hline Mean(2013-2018),RUS & 0.389 & 0.392 & \\
\hline & 0.273 & 0.284 & \\
\hline & & & \\
\hline
\end{tabular}

Source: compiled by the authors, the calculations performed according to the proposed methodology using the data from Tables 1 and 2.

Thus, according to the conducted research on the comparative efficiency of state support for natural gas production (expressed in units of the country's GDP), in several OECD developed economies (the USA, Canada, Norway, and Australia) and some BRICS emerging economies (China, Brazil, and Russia), over the period from 2013 to 2018 Russia had lower efficiency than the OECD countries with developed economies (the USA, Canada, and Australia), which means that Russia's state support for energy subsidies should be reformed.

A valuable example for Russia in reforming the state support for energy subsidies is more than a century of US experience in regulating subsoil use (Atnashev, 2016) and removing a number of barriers that impede the natural development of this business. The main factor that differentiates the United States from other mining countries is the minimal regulation of subsoil use and competitive structure of the industry, where hundreds of small and medium-sized companies compete with leaders, constantly testing new technological ideas. In addition to the minimal regulation pertaining to subsoil use, the country needs an effective financial market and investments protection. Due to these factors, the innovation experience gained during the last decade has allowed the United States to significantly transform this industry and to double hydrocarbon production.

Even during the periods of relatively low oil prices, Russia could increase investments and technological growth in this sector if it deregulated subsoil use and opened the oil and gas industry to private investment. 


\section{ENTREPRENEURSHIP AND SUSTAINABILITY ISSUES}

ISSN 2345-0282 (online) http://jssidoi.org/jesi/

2020 Volume 7 Number 3 (March)

http://doi.org/10.9770/jesi.2020.7.3(22)

Russian oil, gas and chemical industries are the areas that require more efficient state support. Although Russia is one of the leading oil and gas producers with significant hydrocarbon reserves, the oil and gas chemical industry, which could effectively monetize this strategic advantage, represents only $1.5 \%$ of the Russian economy. Pyrolysis plants, the foundation of the Russian petrochemical industry, were built in the second half of the 20th century, and have since only been modernized and expanded (VYGON, 2017).

In 2012, the Ministry of Energy of the Russian Federation approved the Development Plan for the Russian Gas and Petrochemical Industry that would be in effect until 2030 (hereinafter referred to as the Plan-2030). The strategy proposed as a part of the Plan includes building six bespoke large gas and petrochemical conglomerate clusters in order to solve one of the key structural tasks - to facilitate the development of petrochemical production. Each cluster is envisaged to contain a complete production chain - from hydrocarbon extraction to the production of final consumer goods. Such a development strategy was chosen due to the successful international experience with similar initiatives.

The strategy chosen within the Plan-2030 that entails creating such clusters is the best solution for the development of the petrochemical industry in Russia. The government will play an active role in the implementation of this approach, as it will provide benefits and subsidies to newly created enterprises. Most importantly, it will participate in constructing the infrastructure for future clusters, as well as provide them with raw materials.

This measure aimed at increasing the efficiency of state support for energy subsidies in Russia will ensure the diversification of the Russian economy due to the increased economic complexity index (ECI) (Hausmann and Hidalgo, 2009). Empirical evidence indicates that economic development necessitates the implementation of more complex methods of production, which would typically yield higher value added per an employee (van der Ploeg et al., 2017).

These assertions are based on the fact that complex products require a wider range of skilled workers, related industries, and inclusive institutions that make these products economically competitive. Conversely, simple products and activities related to resource utilization are mainly associated with resource intensity, low labor costs, routine activities, and economies of scale.

The directed development and support of the petrochemical industry requires an integrated approach that would cover the entire chain, from the extraction of raw materials to the creation of final products. The system of state subsidies should be aimed at solving specific state problems (for example, construction of pyrolysis plants and transport infrastructure). It should comply with the development strategy of the related industries, without creating artificial imbalances when stimulating the development of production depending on the type of raw materials (VYGON, 2017).

Low efficiency of state support for energy subsidies in Russia has been noted in other studies. For instance, Gerasimchuk (2012), Lunden and Fiertoft (2014) analyzed in detail the size and efficiency of government subsidies to the Russian oil and gas sector and identified more than 30 federal subsidy schemes for oil and gas producers in Russia that were in place in the 2009-2010 period.

Lunden and Fiertoft (2014) further noted that 17 of these 30 schemes amounted for USD 8.1 billion in 2009 and USD 14.4 billion in 2010, equivalent to $4.2 \%$ and $6.0 \%$ of the total value of oil and gas production in Russia in 2009 and 2010, respectively.

Moreover, Gerasimchuk (2012) found that subsidies were provided in the form of direct support (targeted budget financing, state lending on concessional terms, etc.), or in an indirect form, for example, when the government 


\section{ENTREPRENEURSHIP AND SUSTAINABILITY ISSUES}

ISSN 2345-0282 (online) http://jssidoi.org/jesi/

2020 Volume 7 Number 3 (March)

http://doi.org/10.9770/jesi.2020.7.3(22)

recovered the damage due to industrial accidents or provided concessional conditions for oil and gas companies to use state-owned infrastructure.

The study "State Support for Oil and Gas Production in Russia. A Subsidizing Role in the Development of Projects of "Yamal LNG" and "Prirazlomnoye" (Lunden and Fiertoft, 2014) provided substantial evidence that government support for the Yamal LNG and Prirazlomnoye projects was inefficient and unprofitable, and the net social benefits from their implementation are doubtful. The researchers found that after paying taxes, both projects would be unprofitable under the current Russian tax system (when it is not profit, but income that is taxed). However, "corrective" tax benefits and other state support measures do not follow the system criteria, but are applied to "status" projects. According to the authors of the study, "the status is determined according to criteria that are not always clearly stated. Although the government reserves the right to select favorite projects, there is no guarantee that other projects that could bring more revenues to the Russian state will not be overlooked" (Gerasimchuk, 2012).

The conclusions of this paper, as well as the results of the studies (Gerasimchuk, 2012; Lunden and Fiertift, 2014), prove the poor quality of Russian state administration and institutions as they are incapable of pursuing an effective budget and energy policy. There is an urgent need to reform energy subsidies, to create a single mechanism for monitoring and evaluating the funding of subsidies on fossil fuels according to the set objectives and with special focus on their social and environmental impacts.

\section{Conclusions}

The research findings of cross-country (the USA, Canada, Norway, Australia, China, Brazil, and Russia) analysis of the comparative efficiency of state support for natural gas production in 2013-2018 indicate the low result of Russia. In practice, the Russian state policy does not provide for the intense development of the oil and gas sector. Urgent measures should be taken to end inefficient energy subsidies that stimulate wasteful consumption of non-renewable raw materials and fossil fuels, which will correspond to Russia's obligations as a member of the G20.

Comprehensive research should be conducted on the economic and financial implications of ending fossil fuel subsidies. In this regard, DEA models for evaluating the relative efficiency of government support for energy subsidies can be a powerful tool to support governments in the complex and crucial task of reforming their energy policies in line with global climate goals.

\section{References}

Akhremenko, A. 2013. Efficiency and Efficiency in Russian Regional Healthcare. In Russia's Regions and Comparative Subnational Politics. L., NY: Routledge, 120-140.

Akhremenko, A. S. 2013a. Evaluation of the efficiency of the state in the production of public services: theoretical model and method of measurement, Policy. Political Research, 1: 113-135.

Atnashev, M. 2016. What Russia can and cannot produce instead of oil. Moscow Carnegie Center. Retrieved from http://carnegie.ru/commentary/?fa=62888

Charnes, A., Cooper, W. W., Golany, B., Seiford, L. M., Stutz, J. 1985. Foundations of data envelopment analysis and Pareto-Koopmans empirical production functions, Journal of Econometrics, 30(1): 91-107. 


\section{ENTREPRENEURSHIP AND SUSTAINABILITY ISSUES}

ISSN 2345-0282 (online) http://jssidoi.org/jesi/

2020 Volume 7 Number 3 (March)

http://doi.org/10.9770/jesi.2020.7.3(22)

Coady, D., Parry, I., Le Nghia, P., Baoping, Sh. 2019. Global Fossil Fuel Subsidies Remain Large: An Update Based on Country-Level Estimates. IMF Working Paper. WP/19/89. May.

Debreu, G. 1951. The coefficient of resource utilization, Econometrica: Journal of the Econometric Society, 19: $273-292$.

Emrouznejad, A., Parker, B., Tavares, G. 2008. Evaluation of research in efficiency and productivity: a survey and analysis of the first 30 years of scholarly literature in DEA, Socio-Economic Planning Science, 42(3): 151-157.

Farrell, M. J. 1957. The measurement of productive efficiency, Journal of the Royal Statistical Society. Series A (General), 1957: 253-290.

Forsund, F. R., Hjalmarsson, L. 1974. On the measurement of productive efficiency, The Swedish Journal of Economics, 76: 141-154.

Gerasimchuk, I. V. 2012. State support of oil and gas production in Russia: what price? Research of the World Wide Fund for Nature $(W W F)$ and Global initiative of subsidies of the International institute of sustainable development (IISD). Moscow - Geneva: Published by WWF of Russia and IISD.

Global Energy Statistical Yearbook. 2019. Retrieved from https://yearbook.enerdata.ru

Grigoriev, L. M., Kurdin, A. A. 2014. Power subsidies in the modern world. The countries of "G20 “. Moscow: Asmin Print.

Hausmann, R., Hidalgo, C. 2009. The building blocks of economic complexity, Proceedings of the National Academy of Sciences of the United States of America, 106(26): 10570-10575. Retrieved from https://oecd.org/fossil-fuels/publication/OECD-IEA-G20-Fossil-FuelSubsidies-Reform-Update-2019.pdf

International Energy Agency. Fossil-Fuel Subsidies: Methodology and Assumptions. 2015. Paris: International Energy Agency.

Khezrimotlagh, D., Salleh, S., Mohsenpour, Z. 2013. A New Method for Evaluating Decision Making Units in DEA, Journal of the Operational Research Society, 65(1): 694-707.

Koopmans, T. C. 1951. Analysis of production as an efficient combination of activities, Activity analysis of production and allocation, 13: 33-37.

Lunden, L. P., Fiertoft, D. 2014. State support of oil and gas production in Russia. A subsidizing role in development of projects of "Yamal $L N G$ " and "Prirazlomnoye". Geneva - Oslo - Moscow. Published by Economics from the University of Oslo.

OECD. Inventory of Support Measures for Fossil Fuels. Data Base Brochure. 2019. Retrieved from http://www.oecd.org/fossilfuels/data/OECD-Fossil-Fuels-Support-database-brochure-2019.pdf

Onrubia-Fernández, J., Jesús Sánchez Fuentes, A. 2017. How costly are public sector inefficiencies? A theoretical framework for rationalising fiscal consolidations, Economics: The Open-Access, Open-Assessment E-Journal, 11(2017-35): 1-19.

Ploeg van der, F., Malova, A., Saltan, A. 2017. Harnessing hydrocarbon revenues: reflections on Russia, St Petersburg University Journal of Economic Studies, 33(3): 348-363.

Russian Petrochemical Industry in Russia: Should We Expect Changes? 2017. The website of VYGON Consulting, December. Retrieved from https://vygon.consulting/upload/iblock/3ae/vygon consulting russian petrochemistry 2017 summary.pdf

Stiglitz, J. E., Stern, N., Duan, M., Edenhofer, O., Giraud, G., Heal, G., La Rovere, E. L., Morris, A., Moyer, E., Pangestu, M., Shukla, P.R. 2017. Report of the high-level commission on carbon prices. Carbon Pricing Leadership Coalition, 29.

Tone, K. 2001. A slacks-based measure of efficiency in data envelopment analysis, European Journal of Operational Research, 130(3): 498-509.

Update on Recent Progress in Reform of Inefficient Fossil-fuel Subsidies that Encourage Wasteful Consumption. Contribution by the International Energy Agency (IEA) and the Organisation for Economic Co-operation and Development (OECD) to the G-20 Energy Transitions Working Group in consultation with International Energy Forum (IEF), Organization of Petroleum Exporting Countries (OPEC) and the World Bank. 2nd Energy Transitions Working Group Meeting. San Carlos de Bariloche, 13-14 June 2018.

US Energy Information Administration. N.d. Retrieved from https://www.eia.gov/ 


\begin{abstract}
Alan Kanamatovich KARAEV is a Doctor of Sciences (Engineering), Professor, Senior Staff Scientist of the Financial Policy Center of the Public Finance Department, Financial University under the Government of the Russian Federation. Scientific specialty: the problems of coordinating strategic, macroeconomic, and budget forecasting; studying the problems of interaction between the state, financial, and real sectors of the national economy; assessing the stability of the budget system of the national economy based on the development of computational methods and computer modelling methods for nonlinear behaviour of financial and economic systems and processes.
\end{abstract}

ORCID ID: https://orcid.org/0000-0002-5120-7816

Vadim Vitalievich PONKRATOV is a Candidate of Sciences (Economics), Director of the Financial Policy Center of the Public Finance Department, Financial University under the Government of the Russian Federation. Scientific specialty: state financial policy, evaluation of its effectiveness; management of oil and gas budget revenues, strategies for the formation and use of sovereign funds resources; natural rent and instruments of its withdrawal; tools of state financial incentives foreconomic development.

ORCID ID: https://orcid.org/0000-0001-7706-5011

Andrey Igorevich MASTEROV is a Candidate of Sciences (Economics), Leading Research Scientist of the Financial Policy Center of the Public Finance Department, Financial University under the Government of the Russian Federation. Scientific specialty: enhancing the management of sovereign wealth funds; improving the quality of budget planning and forecasting using program-targeted approaches; study of budget tools to stimulate economic growth, import substitution and export.

ORCID ID: https://orcid.org/0000-0002-5531-1047

Andrey Sergeevich POZDNYAEV is a Doctor of Sciences (Economics), Leading Researcher of the Research Institute of Special Engineering, Bauman Moscow State Technical University. Scientific specialty: national tax systems, fiscal policy, verification of economic indicators and quantitative methods of analysis.

ORCID ID: https://orcid.org/0000-0003-4038-6609

Nikolay Vladimirovich KUZNETSOV is a Doctor of Sciences (Economics), Candidate of Sciences (Engineering), Director of the Economics and Finance Institute of the State University of Management. Scientific specialty: building systems of financial and economic management of enterprises; financial and strategic management, financial analysis, economic and mathematical modeling and forecasting.

ORCID ID: https://orcid.org/0000-0001-9897-1531

Register for an ORCID ID:

https://orcid.org/register

Copyright (C) 2020 by author(s) and VsI Entrepreneurship and Sustainability Center

This work is licensed under the Creative Commons Attribution International License (CC BY).

http://creativecommons.org/licenses/by/4.0/

(c) (i) Open Access 